\title{
PENGUATAN PENDIDIKAN KARAKTER MELALUI CERITA RAKYAT PADA PELAJARAN BAHASA INGGRIS DI PERGURUAN TINGGI
}

\author{
Engliana, Nina Dwiastuty, Ira Miranti, Nurjanah \\ Fakultas Pendidikan Bahasa Inggris, Universitas Indraprasta PGRI, \\ Jakarta \\ engliana.seok@gmail.com
}

\begin{abstract}
Abstrak: Cerita rakyat dan dongeng dianggap materi tidak formal dalam penyusunan materi di perguruan tinggi karena struktur narasi sederhana, pemakaian kalimat dan kosakata sehari-hari, dan isi cerita yang tidak ada kaitan dengan materi formal yang dibahas dan dikerjakan dalam tugas atau ujian. Tujuan penelitian ini adalah untuk menganalisis alasan, keuntungan, dan batasan penggunaan cerita rakyat dan dongeng sebagai materi yang patut diperhitungkan oleh para pendidik tingkat perguruan tinggi untuk penguatan pendidikan karakter. Penelitian ini merupakan kajian pustaka dengan menggunakan teknik analisis wacana. Sumber data utama berupa kumpulan pustaka berupa artikel hasil eksperimen, wacana atau gagasan tertulis dalam artikel, dan hasil pemaparan ide lewat seminar tentang cerita rakyat pada pelajaran bahasa Inggris di perguruan tinggi. Pengumpulan data dengan teknik pembacaan teks. Data yang terkumpul dianalisis dengan teknik analisis isi. Hasil penelitian menunjukkan bahwa cerita rakyat tidak hanya dapat dipakai dalam pelajaran budi pekerti dan perkembangan karakter, tetapi juga bermanfaat untuk pembelajaran bahasa Inggirs dalam konteks pendidikan formal di perguruan tinggi. Kesadaran akan konten naratif khusus budaya dan nilai moral dalam setiap cerita lokal atau internasional dapat membantu mahasiswa perguruan tinggi untuk penguatan karakternya.
\end{abstract}

Kata Kunci: cerita rakyat, perguruan tinggi, pendidikan karakter, pengajaran bahasa asing.

\section{STRENGTHENING CHARACTER EDUCATION THROUGH FOLKSTALES IN ENGLISH LESSONS IN HIGHER EDUCATION}

\begin{abstract}
Folktales and fairy tales are considered informal material in the preparation of material in higher education because of the simple narrative structure, daily use of sentences and vocabulary, and story content that has no connection with formal material that is discussed and worked on in assignments or examinations. The purpose of this research paper is to analyze the reasons, advantages, and limitations of using folktales and fairy tales as material that should be taken into college-level educators to strengthen character education. This research is a literature study using discourse analysis techniques. The main data source in the form of a collection of literature in the form of articles of experimental results, discourse or ideas written in the article, and the results of the presentation of ideas through seminars about folktale in English lessons in college. Data were collected by text reading techniques. The collected data ware
\end{abstract}


analyzed using content analysis techniques. The results showed that folkltales can not only be used in the lessons of character building and character development, but also beneficial for English language learning in the context of formal education in higher education. Awareness of specific cultural narrative content and moral values in any local or international story can help college students to strengthen their character.

Keywords: folktales, higher education, character education, foreign language teaching.

\section{PENDAHULUAN}

Tulisan ini membahas satu aspek dari banyak aspek yang ditawarkan dari hasil penelitian lain tentang adaptasi dan penggunaan materi nonformal sebagai sisipan materi atau materi tambahan dalam mata kuliah keahlian khusus di jurusan Pendidikan Bahasa Inggris atau bahasa asing lainnya. Salah satu mata kuliah keahlian berbahasa yaitu Listening Comprehension (atau menyimak) di tingkat perguruan tinggi. Dasar dari usaha penggunaan materi nonformal bermuatan lokal dan internasional berasal dari pernyataan tentang penguatan karakter dalam pendidikan dasar oleh pihak pemerintah Indonesia. Selain pelaksanaannya di pendidikan dasar, ada baiknya bila terjadi pengulangan di tingkat pendidikan tinggi, yaitu tingkat sekolah tinggi atau universitas untuk tetap menguatkan karakter generasi para calon penerus bangsa. Menteri Pendidikan dan Kebudayaan Republik Indonesia, Muhadjir Effendy, menyatakan bahwa program Penguatan Pendidikan Karakter (PPK) menurut Peraturan Presiden Nomor 87 Tahun 2017 tentang Penguatan Pendidikan Karakter berisi pelaksanaan penguatan pendidikan karakter melalui kurikulum berbasis luas (broad-based curriculum). Kurikulum ini menyatukan tiga lingkungan belajar: keluarga, sekolah, dan masyarakat (Effendy, 2018). Meskipun PPK ini menyasar pada sekolah dasar dan menengah, namun bila melihat bahwa ekosistem pendidikan yang sehat dari lingkungan sekitar siswa sekolah, maka tidak salah bila konsep yang sama diadaptasi untuk ekosistem pendidikan di perguruan tinggi.

$\begin{array}{ccc}\text { Ekosistem } & \text { perguruan tinggi } \\ \text { perlu juga } & \text { memahami dan }\end{array}$ mengalami proses penguatan pendidikan karakter lewat nilai moral yang diajarkan melalui materi pembelajaran yang disampaikan. Materi tidak harus disampaikan khusus, tetapi dapat dilaksanakan melalui sisipan materi nonformal dalam materi formal yang diberikan oleh pengampu mata kuliah yang cocok dengan dua macam materi tersebut. Fungsi sisipan pendidikan moral untuk penguatan pendidikan karakter dengan konteks perguruan tinggi adalah menggerakkan imajinasi moral dan emosi positif. Sedangkan tujuannya untuk menghasilkan manusia dewasa awal (young adults) yang siap untuk berkiprah di tahap selanjutnya yaitu 
tahap manusia dewasa yang berakhlak dan baik budi pekertinya sehingga dapat membina generasi berikutnya.

Dalam disertasinya yang diajukan tahun 2015 lalu, Nurudin (UMY, 2015) menyampaikan suatu wacana betapa pentingnya pendidikan karakter yang holistikintegratif dalam pelajaran bahasa Inggris. Bahasa Inggris bisa menjadi wahana untuk penanaman nilai-nilai karakter guna mencapai ketiga kompetensi tersebut. Alasannya, karena Bahasa Inggris merupakan bahasa asing pertama di Indonesia yang dianggap penting guna mengembangkan ilmu pengetahuan dan berhubungan dengan bangsabangsa lain. Namun pada kenyataannya, kesuksesan pengajaran bahasa Inggris di Indonesia masih belum maksimal. Penyimpangan seksual, tawuran, rendah diri, konsumsi obat-obatan terlarang adalah masalah sosial dan mental yang dihadapi oleh para generasi dewasa awal tersebut. Tumpukan masalah ini menjadi bukti bahwa perlu adanya pendidikan karakter, berikut penguatan yang berkesinambungan setelah para siswa menjalani pendidikan formal wajib 12 tahun yang telah dicanangkan oleh pemerintah, yaitu di perguruan tinggi dalam bentuk sisipan materi pendidikan karakter yang holistikintegratif.

Dari paparan di atas jelaslah bahwa penguatan pendidikan karakter harus dilakukan melalui semua mata pelajaran, tidak hanya melalui pendidikan agama dan pendidikan kewarganegaraan saja. Penguatan pendidikan karakter melalui pelajaran bahasa Inggris penting dilakukan bagi mahasiswa di perguruan tinggi melalui berbagai materi ajarnya. Penelitian ini bertujuan untuk mengkaji penguatan pendidikan karakter melalui pelajaran bahasa Inggris bagi mahasiswa di perguruan tinggi, terutama melalui isi materinya tentang cerita rakyat.

\section{METODE}

Penelitian ini berlandaskan pada kajian pustaka dengan menggunakan teknik analisis wacana. Sifat kajian pustaka dalam tulisan ini adalah umum dan berkembang seiring dengan proses penulisan. Sumber data utama adalah kumpulan pustaka berupa artikel hasil eksperimen, wacana atau gagasan tertulis dalam artikel, dan hasil pemaparan ide lewat seminar. Hasil kajian wacana tersebut menjadi data tulisan ini melalui perbandingan antardata dan pembuatan inferensi serta interpretasi. Oleh karena itu, penulisan ini dimulai dengan: 1) pengumpulan pustaka relevan tentang pendidikan karakter, penggunaan cerita rakyat/fabel/materi informal dari hasil penelitian, dan pengajaran bahasa Inggris sebagai bahasa asing yang dipublikasi sebelumnya di tingkat nasional dan internasional fungsinya untuk perbandingan antardata; kemudian 2) pembuatan inferensi dan interpretasi dari seluruh pustaka tersebut di tahap pertama tadi untuk fokus pada masalah inti, yaitu manfaat penggunaan cerita rakyat untuk pendidikan karakter dalam konteks pendidikan bahasa Inggris sebagai bahasa asing di tingkat perguruan tinggi, suatu 
bangun pengetahuan dan wacana sesuai fokus yang diperoleh.

Penelitian ini merupakan kajian pustaka dengan menggunakan teknik analisis wacana. Sumber data utama berupa kumpulan pustaka berupa artikel hasil eksperimen, wacana atau gagasan tertulis dalam artikel, dan hasil pemaparan ide lewat seminar tentang cerita rakyat pada pelajaran bahasa Inggris di perguruan tinggi. Pustaka yang digunakan dalam tulisan ini bersifat sementara karena tidak menjadi pegangan utama oleh karena fokus tulisan ini adalah sebuah wacana untuk meyakinkan pembaca bahwa penting dan perlu adanya materi nonformal seperti cerita rakyat, legenda, atau fabel dalam materi formal di perguruan tinggi.

Pengumpulan data dengan
teknik pembacaan teks untuk menemukan makna dengan memperhatikan wacana yang ada. Keabsahan data diperoleh dari pembacaan berulang, pemeriksaan referensi dengan dokumen lain yang memiliki bahasan berhubungan dengan fokus tulisan ini (crossreferencing) dengan menggunakan kutipan langsung dari dokumen yang bersangkutan. Data yang terkumpul dianalisis dengan teknik analisis isi (content analysis).

\section{HASIL DAN PEMBAHASAN}

Bagian ini memaparkan hasil dan pembahasan sesuai dengan fokus penulisan. Subbagian hasil memaparkan prinsip dasar pendidikan karakter dan model internalisasi pendidikan karakter dalam materi pembelajaran. Sedangkan pada subbagian pembahasan, penulis menyampaikan alasan penting pendidikan karakter di perguruan tinggi, konsep memakai cerita rakyat dalam pembelajaran bahasa Inggris sebagai bahasa asing di mata kuliah tertentu, peran umum media visual di ruang kelas, dan kesadaran akan imajinasi naratif untuk pendidikan karakter dan moral.

\section{Hasil}

Prinsip Dasar dan Nilai
Pendidikan Karakter Andriany (2016: 53-54) mengusulkan beberapa butir prinsip dasar pendidikan karakter sesuai dengan Character Education Quality Standards (Character Education Partnership DC., 2008) sebagai berikut.

1. Mempromosikan nilai-nilai dasar etika sebagai basis karakter.

2. Mengidentifikasikan karakter secara komprehensif agar mencakup pemikiran, perasaan, dan perilaku.

3. Menggunakan pendekatan yang tajam, proaktif, dan efektif untuk membangun karakter.

4. Menciptakan komunitas institusi pendidikan yang memiliki kepedulian.

5. Memberi kesempatan kepada peserta didik untuk menunjukkan perilaku yang baik.

6. Memiliki cakupan terhadap kurikulum yang bermakna dan menghargai peserta didik secara keseluruhan, membangun karakter dan membantunya untuk meraih kesuksesan. 
7. Mengusahakan tumbuhnya motivasi diri para peserta didik.

8. Memfungsikan seluruh staf institusi pendidikan sebagai komunitas moral yang berbagi tanggung jawab untuk pendidikan karakter yang setia pada nilai dasar yang sama.

9. Adanya pembagian kepemimpinan moral dan dukungan luas dalam membangun inisatif pendidikan karakter.

10. Memfungsikan keluarga dan anggota masyarakat sebagai mitra dalam usaha membangun karakter.

11. Mengevaluasi karakter institusi pendidikan, fungsi staf sekolah sebagai tenaga pendidik karakter dan manifestasi karakter positif dalam kehidupan peserta didik.

Sedangkan nilai pendidikan karakter dapat dibagi menjadi 3 kategori (Tappan, 1992: 53), yakni sebagai berikut.

1. Pengetahuan moral (moral knowing) yang terdiri atas: a) kesadaran moral (moral awarreness); b) pengetahuan nilai moral (knowing moral value); c) memahami sudut pandang lain (perpective taking); d) penalaran moral (moral reasoning), e) pembuatan keputusan (desicion making); dan f) pengetahuan diri (selfknowledge).

2. Perasaan moral (moral feeling) yang terdiri atas: a) nurani (conicience); b) harga diri (self-esteem); c) empati (empathy); d) cinta kebaikan (loving the good); e) kontrol diri (self-control); dan f) rendah hati (humanity).

3. Tindakan moral (moral action) yang terdiri atas: a) kompetensi (competence); b) keinginan (will); dan c) kebiasaan (habit).

\section{Model Internalisasi Pendidikan Karakter dalam Materi Pembelajaran}

Fogarty (Andriany, 2016: 96) menyampaikan tiga macam model penyampaian pendidikan karakter dalam materi pembelajaran, yaitu: 1) interdisiplin ilmu, termasuk tipe ini adalah fragmental model, connected model, dan nested model; 2) antardisiplin ilmu, termasuk tipe ini sequenced model, shared model, webbed model, threanded model dan integrated model; dan 3) Inter- dan antardisiplin ilmu, termasuk tipe ini immersed model, dan networked model. Model yang diajukan dalam wacana ini adalah model yang berfokus pada para mahasiswa dan materi yang diintegrasikan dalam materi pembelajaran di perguruan tinggi dengan dosen sebagai pengampu mata kuliah dan pelaksana dari materi pendidikan karakter ini.

\section{Pembahasan \\ Mengapa di Perguruan Tinggi?}

Usia peserta didik di perguruan tinggi umumnya mulai dari $18-22$ tahun. Rentang usia ini ada di dua tahap perkembangan psikologi dari delapan tahap perkembangan psikososial yang dipaparkan oleh Erikson (Erikson \& Erikson, 1998), yaitu tahap adolesen (usia 12-20 tahun) 
dan dewasa awal (young adult) (usia 20-30 tahun) (Hambali, 2013: 149153). Tahap adolesen adalah tahap identitas, yaitu tahap beralihnya dari identitas anak-anak menuju remaja. Oleh karena peralihan ini, identitas anak-anak dianggap masa lalu dan para peserta didik berada dalam masa pencarian identitas baru. Biasanya mereka mencari semacam standar dan pengakuan baru dari teman seumur mereka, bukan dari orang tua mereka lagi. Sekolah dan perguruan tinggi memegang peranan penting dalam proses peralihan ini sebab para peserta didik menghabiskan sebagian besar waktu mereka berada di lingkungan ini. Di usia 18 tahun mereka mulai memasuki masa pendidikan tingkat perguruan tinggi atau ada yang mulai bekerja. Para kelompok pertama dan kedua, sekolah sebelumnya sudah membentuk dasar identitas peralihan para peserta didik ini dan membawa proses peralihan dari masa anak-anak tersebut serta mencari standar identitas dari lingkungan baru mereka. Perbedaan terjadi pada lokasi, lingkungan, dan komunitas terjadi setelah mereka melepaskan sekolah. Kelompok pertama mengenyam pendidikan tinggi dengan lingkungan, komunitas, dan standar yang berbeda dengan kelompok remaja pertama. Kelompok kedua sudah langsung terjun ke dunia kerja dengan standar di lingkungan kerja dan komunitas pekerja tempat kelompok remaja ini bergabung. Lantas, bila kedua kelompok remaja ini mengalami proses peralihan dan pencarian identitas mengapa di perguruan tinggi diperlukan penguatan karakter juga?

Umumnya para remaja lulus sekolah pendidikan dasar 12 tahun dan masuk perguruan tinggi pada usia 18 tahun dan lulus pada usia 22 tahun dengan perhitungan jenjang sarjana dilalui dalam masa belajar empat tahun. Rentang usia 18-22 tahun berada di transisi tahap adolesen dan dewasa awal sehingga patut diingat bahwa bila remaja tersebut perlu dibina dengan baik dan benar, sesuai dengan lingkungan tempat tinggalnya dan juga bisa berkembang menjadi pribadi matang yang siap dengan dunia global. Tahap dewasa awal adalah tahap remaja mencapai: pemahamannya yang akan dirinya sendiri pada saat adolesen akan memudahkannya untuk menyatukan dirinya dengan identitas orang lain. Seseorang yang sudah menginjak masa dewasa dan mulai memiliki kemampuan untuk menyatukan identitas diri dan identitas orang lain tanpa takut akan kehilangan identitas dirinya hal inilah yang disebut dengan keakraban (Hambali, 2013: 152).

Hasanah (2013) menyampaikan bahwa ada tiga jalur cara pendidikan karakter dapat dilaksanakan untuk memupuk nilai inti: jujur, cerdas, peduli, dan tangguh, yaitu: a) melalui integrasi dalam pembelajaran; b) manajemen pengelolaan jurusan dan program studi; c) kegiatan mahasiswa. Bagian pertama bisa menjadi langkah pertama pula bagi para pendidik perguruan tinggi untuk melihat bahwa penguatan karakter dapat dimulai tanpa harus melibatkan banyak organisasi dan lembaga. Melainkan dapat bertatap muka langsung dengan para mahasiswa/i. Dharmawan (2014) pun setuju bahwa penerapan pendidikan karakter atau moral di perguruan tinggi memerlukan strategi khusus karena manusia adolesen ini adalah "insan akademis yang kritis". Pembentukan di masa adolesen sangat mempengaruhi 
perkembangan dewasa awal, yaitu saat para peserta didik perguruan tinggi berada di tahun ketiga dan keempat pendidikan tinggi. Tahun pertama dan kedua adalah masa adolesen tahap akhir mereka. Diharapkan bahwa saat para mahasiswa ini menjalani tugas penulisan akhir, sidang skripsi, dan masa melamar pekerjaan, mereka menjadi pribadi yang sudah mulai memahami diri mereka sendiri dan berbaur dengan komunitas dan lingkungan sekitar mereka. Para mahasiswa ini disebut sebagai agent of change, social of control, dan moral force (Dhiu \& Bate, 2018). Pendidikan dan penguatan karakter ini dapat dilihat dari kemampuan para mahasiswa/i mengelola stres akademik atau tekanan mengerjakan tugas akhir, yaitu skripsi dan menghindari tindakan plagiasi (Zuama, 2014).

\section{Cerita Rakyat/Dongeng dalam Materi Pelajaran Bahasa Asing di Perguruan Tinggi}

Para ahli telah membuat pernyataan untuk mempertimbangkan integrasi cerita rakyat dalam bahan formal English as a Foreign Language (EFL) atau Inggris sebagai Bahasa Asing. Lwin (2015) menyarankan penggunaan cerita rakyat untuk mengajar EFL guna mencapai tujuan komunikasi tertentu dan meningkatkan kesadaran lintas budaya. Ia menyebutkan penggunaan analisis linguistik dan struktural cerita rakyat untuk menarik pemahaman dan minat peserta didik tentang bagaimana kosa kata dan pola tata bahasa Inggris dapat digunakan untuk membangun makna. Selain itu, ia juga menentang penggunaan setidaknya dua kisah dari budaya lain yang akan mengungkapkan konten naratif khusus budaya di masing-masing - ada lebih banyak manfaat dalam menggunakan lebih dari satu kisah untuk dibandingkan pemikiran kritis, kesadaran budaya, dan moral pendidikan. Lwin (2014) menawarkan konsep yang ditujukan untuk pengajaran EFL umum, dan terutama dapat digunakan untuk keterampilan membaca dan/atau menulis. Sajak anak-anak untuk mengajar EFL untuk pelajar muda berguna untuk pemahaman dan akuisisi pada usia dini. Meskipun beberapa orang tidak menganggap sajak pembibitan mengandung ikon budaya dari budaya tertentu, namun ada beberapa sajak pembibitan lokal yang mengandung nilai-nilai budaya dan moral dari budaya tertentu.

Banyak penelitian sebelumnya lebih tertarik untuk menyelidiki integrasi cerita rakyat dengan pendidikan dasar dan menengah. Sangat jarang untuk menemukan investigasi empiris tentang cara untuk mengintegrasikan cerita rakyat ke dalam materi formal dalam pendidikan tinggi seperti tingkat perguruan tinggi atau universitas untuk akuisisi bahasa asing. Terlebih lagi, sangat sedikit penelitian yang ditemukan untuk menyelidiki secara empiris penggabungan cerita rakyat di kelas pendengaran EFL di tingkat universitas. Hal ini layak untuk direnungkan karena peraturan pemerintah Indonesia mendukung keberadaan cerita rakyat. dalam Peraturan Menteri Pendidikan dan Kebudayaan Nomor 81A Tahun 2013 tentang Implementasi Kurikulum, Lampiran 2 tentang Pedoman Pengembangan Muatan Lokal. Peraturan ini menyebutkan bahwa kurikulum di setiap tingkat kebutuhan 
pendidikan harus didasarkan pada prinsip diversifikasi dalam pengembangannya dan harus sesuai dengan unit pelajaran, potensi lokal, dan siswa.

Istilah 'di semua tingkat pendidikan' menandakan bahwa pendidikan tinggi tidak dikecualikan dari pendidikan. Crawshaw, McCarthy, \& Carter (1996) berpendapat bahwa kesadaran budaya adalah kunci untuk menghindari transfer fitur wacana yang tidak pantas di seluruh bahasa dan untuk mendorong transfer yang tepat. Dengan kata lain, kesadaran budaya adalah kunci untuk fitur wacana lintas bahasa dan mengintegrasikan cerita rakyat lokal dan internasional ke silabus pendidikan formal diperlukan. Carter \& McCarthy (2017) juga mendesak bahwa fungsi bahasa sering kali paling baik dipahami dalam lingkungan wacana dan bahwa mengeksplorasi bahasa dalam konteks memaksa kita untuk merevisi pemahaman yang dimiliki umum tentang bentuk dan makna bahasa.

Selain menggunakan berbagai cerita, Bean (2013: 550) menyarankan agar memanfaatkan kisah-kisah tradisional karena popularitas dan daya tarik universal mereka, dapat dengan mudah digunakan untuk menambah pelajaran pelajar bahasa awal atau kursus yang lebih maju yang mengintegrasikan keterampilan mendengarkan, berbicara, membaca, dan menulis. Lingkungan wacana menunjukkan bahwa bahasa harus dipelajari dengan baik dalam konteks yang sesuai, yang merupakan tempat yang sangat baik untuk cerita rakyat muncul dalam materi kelas.

Materi mata kuliah Menyimak (biasa dikenal dengan listening comprehension) dan Dikte Ulangan Bahasa Inggris (atau dictation) untuk peserta didik EFL sebagian besar mencakup teks yang diucapkan naskah (Read, 2018; Wagner, 2018) yang dibaca dan diucapkan dengan hati-hati oleh aktor suara. Paparan ini menyulitkan peserta didik untuk memahami percakapan yang sebenarnya dan kehidupan nyata. Paparan sebaliknya harus ditambahkan ke dalam bahan mendengarkan, yaitu teks yang diucapkan tanpa naskah. Yang terakhir adalah asli dan lebih dekat dengan situasi kehidupan nyata; menjelaskan kepada peserta didik bahwa pelafalan, nada, dan intonasi bahasa berbeda dari teks yang diucapkan dalam naskah yang diberikan dalam teks yang ditentukan. Dengan demikian, untuk menggabungkan teks lisan tanpa naskah dalam kelas Menyimak, maka bahasa dan tema untuk mendengarkan berbasis tes standar internasional (mis. Test of English as Foreign Language atau dikenal dengan TOEFL) diganti dengan jenis bahasa dan tema yang menggunakan tipe teks informal, yaitu dongeng, dan cerita rakyat lokal, untuk meningkatkan kompetensi komunikatif peserta didik dan hubungan positif antara bahan yang menarik dan belajar bahasa. Beberapa penelitian tentang manfaat penggunaan materi informal (Ismail \& Alexander, 2005; Read, 2018) yang dilakukan telah menunjukkan bahwa menggunakan materi mendengarkan yang dekat dengan pengaturan bahasa yang spesifik dan unik akan membantu pelajar bahasa asing memperoleh keterampilan bahasa yang ditargetkan bersama dengan tujuan komunikatif khusus dan kesadaran lintas budaya. Seperti yang dikatakan Wagner (2014) 
bahwa materi semacam itu akan membantu pelajar menyadari karakteristik teks dan fonologis dari teks yang tidak ditulis, mempersiapkan peserta didik L2 untuk dapat memahami bahasa lisan di dunia nyata, dan mempromosikan kompetensi komunikatif peserta didik.

Banyak pendidik EFL memilih dongeng atau dongeng terkenal di ruang kelas mereka, yaitu, cerita seperti Sleeping Beauty, Snow White, Hansel, dan Gretel adalah di antara judul-judul paling populer dalam praktik ruang kelas. Saat ini banyak cerita dongeng lain yang bisa dipakai sebagai alat bantu, seperti Frozen, Pocahontas cerita yang mengandung nilai sejarah dan moral. Pilihan berguna untuk menarik minat peserta didik untuk mendengarkan sesuatu yang akrab dengan dunia mereka. Pilihan ini juga merupakan titik awal yang baik untuk memulai pembelajaran dengan tujuan untuk mendapatkan minat dan mengurangi kecemasan bagi para pendidik dan peserta didik. Mendengarkan topik atau tema yang sudah dikenal juga mendorong peserta didik untuk menggunakan strategi yang berbeda untuk mengatasi perasaan tidak nyaman ketika berhadapan dengan kesulitan dalam kelas pemahaman mendengarkan EFL, misalnya, kosakata dan percakapan pragmatis.

Chou (2015) menunjukkan bahwa efektivitas adopsi strategi tertentu dipengaruhi oleh keakraban topik dan pengalaman pribadi. Dengan demikian, peserta didik akan dapat mengembangkan strateginya untuk mengatasi kesulitan-kesulitan ini dan dapat memperoleh kepercayaan diri untuk tes dan topik berikutnya yang membutuhkan strategi pemecahan masalah yang lebih maju. Namun, itu berguna untuk membawa cerita rakyat lainnya yang tidak dianggap standar, namun masih menggambarkan budaya dan nilai-nilai tertentu. Tujuannya di sini, sekali lagi adalah untuk memperkaya para pendidik dan peserta didik dengan memaparkan variasi pada bahan-bahan yang dipakai di kelas. Oleh karena itu, menggunakan cerita dari budaya lokal tidak hanya akan membantu para peserta didik untuk melepaskan perasaan gelisah mereka tetapi juga mendorong mereka untuk menggunakan strategi mendengarkan yang berbeda untuk memahami dan menafsirkan pesan.

Sementara memilih tingkat keakraban untuk cerita yang akan digunakan di kelas, ada juga studi lain yang menunjukkan cara guru memberikan instruksi untuk strategi mendengarkan dan tugas-tugas telah memungkinkan para siswa tidak hanya mengembangkan strategi mereka untuk mengubah tugas tetapi juga mampu mengatur motivasi dan minat mereka pada tingkat tinggi selama proses mendengarkan. Yeldham dan Gruba mengadakan studi longitudinal pada empat siswa EFL Taiwan yang menyelidiki strategi mendengarkan tertanam yang diberikan langsung oleh para peneliti dan juga dikombinasikan dengan partisipasi mereka. Hasil penelitian menunjukkan bahwa semua peserta didik mengembangkan strategi seimbang top-down dan bottom-up, kebanyakan dengan mengintegrasikan strategi yang sesuai dari kursus ke dalam repertoar mendengarkan mereka. Selain itu, mereka juga mengembangkan beberapa yang berhubungan dengan orang dan tugasbidang terkait, termasuk kepercayaan diri, motivasi, dan perasaan kontrol 
mereka terhadap proses mendengarkan (Yeldham \& Gruba, 2016: 1).

\section{Pemanfaatan Materi Visual dan Multimodalitas}

Kisah-kisah sastra lisan seperti cerita rakyat tradisional sering dianggap sebagai 'struktur cerita dan kompleksitas kosa kata yang terlalu sederhana' atau 'kurang rumit', dan peserta didik - sebagai pembelajar bahasa - tidak akan mendapat manfaat darinya. Menggabungkan teks lisan yang diucapkan dan bahan visual adalah masalah lain yang dipaksakan ketika pendidik ingin mempertimbangkan literasi multimoda dalam materi pemahaman menyimak. Dapat dikatakan bahwa tidak ada cara mudah untuk menemukan bahan yang ideal untuk tujuan tersebut. Literasi multimoda dalam pembelajaran bahasa mendorong peserta didik untuk mengalami berbagai komunikasi dan representasi dari gambar, gerakan, tulisan, dan ucapan (Sanchez, Gu, Kunze, \& Inami, 2015). Tantangannya terletak di sini bagaimana kisah-kisah tersebut harus dimasukkan sebagai konten dalam pengajaran keterampilan bahasa, khususnya, pengajaran EFL di lingkungan lokal dan pendidik atau instruktur. Selain materi tanpa naskah yang akan digunakan sebagai model di kelas, menggunakan materi visual sebagai naskah film untuk keterampilan mendengarkan dan berbicara, kanal YouTube dan/atau video (Watkins \& Wilkins, 2011) dapat menjadi media pengajaran yang bagus untuk menarik minat dan motivasi peserta didik. Ada banyak pilihan untuk memanfaatkan media visual di era teknologi digital saat ini. Mereka juga memberikan hasil yang menjanjikan bagi pendidik dan peserta didik dalam suasana bahasa asing - di saat bahasa yang dipelajari tidak digunakan di luar ruang kelas. Salah satu contoh multimodalitas dalam pengajaran pendidikan karakter dalam materi pelajaran adalah dengan mengubah cerita rakyat ke dalam bentuk cerita bergambar. Setiartin (2016) menemukan dalam penerapan strategi ini dalam konteksnya untuk peningkatan kemampuan membaca apresiatif. Strategi ini dapat diadopsi sesuai dengan tujuan pembelajaran, yaitu pemahaman materi dan dapat ditingkatkan dengan tambahan (audio) visual sebagai alat bantu. Para guru perlu memberikan pertimbangan yang cermat terhadap jenis media yang akan digunakan di kelas untuk memastikan bahwa para peserta didik memahami bagaimana komponen-komponen linguistik dan wacana juga unsur-unsur budaya diekspresikan dalam bahasa target dan memiliki waktu yang cukup untuk mempraktikkan bahasa.

\section{Imajinasi Naratif untuk Penguatan Karakter}

Nussbaum (2018) berpendapat bahwa ada tiga kemampuan untuk dipertimbangkan ke dalam persiapan peserta didik menjadi global citizenship atau anggota masyarakat global di kemudian hari: (1) kemampuan berpikir kritis tentang lingkungan atau tradisi yang ada dan menyampaikan perbedaan pendapat dengan cara yang baik dan demi kepentingan bersama; (2) kemampuan berpikir luas atau global, bukan hanya berpikir dalam lingkup grup atau wilayah tertentu saja; (3) memiliki imajinasi naratif. Imajinasi naratif adalah kemampuan membayangkan bagaimana rasanya berada di posisi seseorang yang sangat berbeda dari diri 
sendiri atau dengan kata lain, orang dengan imajinasi naratif dapat menempatkan dirinya seolah-olah dalam posisi orang lain, sehingga bisa memahami keadaan, tindakan, dan pola pikir orang lain tersebut. Dalam konteks, bercerita, maka kemampuan imajinasi naratif dapat diajar, dibina, dan dipupuk oleh karena lewat narasi atau cerita maka si pendengar cerita tersebut dapat membayangkan tokoh dalam cerita, keadaan atau suasana dalam cerita, dan bahkan berempati dengan si tokoh cerita tersebut lewat narasi yang dituturkan dan imajinasi si pendengar itu sendiri. Empati adalah hasil dari keterlibatan emosional yang secara tidak langsung muncul dari kisah yang kita dengar. Bercerita dan mendengarkan cerita dapat membantu dalam memahami perspektif seseorang, yang memungkinkan untuk memiliki empati dan mencari solusi atau penutup dari kedua belah pihak sudut pandang seseorang dan orang lain. Namun selain narasi dan imajinasi penting, ada satu faktor lain yang ikut menentukan perspektif si pencerita dan si pendengar, yaitu faktor memori atau ingatan.

Samuelson (2008) juga merekomendasikan ide imajinasi moral untuk pemecahan masalah dan kreativitas. Imajinasi moral dalam konteks ini adalah membangkitkan proses kognitif siswa untuk membangun emosi empati pada siswa. Dia menyelidiki pemaparan sejumlah klip film produksi Hollywood untuk merangsang imajinasi moral 366 siswa sekolah dasar kelas tiga sampai kelas delapan dari dua daerah pedesaan di Georgia, AS. Hasil studinya menunjukkan bahwa semakin lama paparan, semakin banyak tema pengakuan moral yang dapat diperoleh peserta didik dalam periode yang ditentukan. Selain ide imajinasi moral, Hustvedt (2011) mengusulkan gagasan 'ingatan 'dan 'imajinasi' yang didorong di bawah emosi dan sering mengambil bentuk naratif. Dengan demikian, mengirim pesan dalam bentuk cerita akan memungkinkan pembicara dan pendengar pesan mencapai tujuan mereka sendiri. Para pembicara menceritakan ingatan dan imajinasi mereka tentang pesan tertentu melalui kata-kata dan mengisinya dengan emosi masa lalu pribadi dan nonpribadi mereka yang tertanam dalam ingatan dan imajinasi yang menghasilkan pengalaman emosional yang mendorong dalam memproses pesan dari sudut pandang pendengar. Dengan kata lain, narasi akan membangkitkan emosi dan imajinasi pendengar dan pendengar karena pendengar tersebut akan berusaha memahami narasi dengan cara mengaitkannya dengan latar belakang pengetahuan dan pengalamannya. Jadi, dapat dikatakan bahwa mendongeng juga dapat meningkatkan pemahaman pendidikan dan pemahaman emosional. Tabel 1 dan Tabel 2 adalah contoh aktivitas sisipan yang dapat dikerjakan di kelas Menyimak bahasa Inggris di perguruan tinggi yang berusaha mengintegrasi literasi multimoda, imajinasi naratif, materi audio-visual, pendidikan moral, serta keahlian berbahasa lainnya yang tercakup dalam kegiatan tambahan setelah para mahasiswa menonton tampilan cerita. 
Tabel 1. Contoh Kegiatan Sisipan untuk Materi Budaya Lokal

\begin{tabular}{|c|c|}
\hline & Classroom Activity \\
\hline $\begin{array}{l}\text { Background } \\
\text { girl that tries } \\
\text { her. } \\
\text { Story Theme: }\end{array}$ & $\begin{array}{l}r y: \text { "Timun Emas" is a Javanese folktale telling the story of a brave } \\
\text { escape and survive from an evil green giant that tried to catch and eat } \\
\text { eaky tricks, bravery, good versus evil, perseverance }\end{array}$ \\
\hline Aims & $\begin{array}{l}\text { Skills - listening for details } \\
\text { Language - narrative text } \\
\text { Other - cooperation, memorizing }\end{array}$ \\
\hline Organization & Groups of three to five students \\
\hline Preparation & $\begin{array}{l}\text { Video of 'Timun Emas'; A piece of blank paper for students to } \\
\text { write their stories }\end{array}$ \\
\hline Time & $45-60$ minutes \\
\hline $\begin{array}{l}\text { Procedure } \\
\text { Step 1: The i } \\
\text { should be play } \\
\text { remind the stu } \\
\text { not allowed to } \\
\text { encourage the } \\
\text { Step 2: The cl } \\
\text { paper. The gr } \\
\text { instructor on t } \\
\text { continuation ( } \\
\text { discuss the de } \\
\text { stories. }\end{array}$ & $\begin{array}{l}\text { ructor plays the video and the students watch carefully. The video } \\
\text { twice. First viewing, they have to listen carefully. Second viewing, } \\
\text { nts to listen the video for a purpose, i.e. listening for details. They are } \\
\text { ke notes for the } 1^{\text {st }} \text { listening, but for the next viewing, the instructors } \\
\text { to take notes. } \\
\text { s is divided into groups. Each group should have one piece of blank } \\
\text { ps now follow the instructions to look at the pictures shown by the } \\
\text { board/projector (see Appendix 1). The instruction tells them to write a } \\
\text { sequel) of 'Timun Emas'. Give them approximately } 15 \text { minutes to } \\
\text { ils of the story sequel, and another } 30 \text { minutes to write down their }\end{array}$ \\
\hline Extension & \\
\hline $\begin{array}{l}\text { The instructor } \\
\text { may have app } \\
\text { other question } \\
\text { taken by Timu }\end{array}$ & $\begin{array}{l}\text { an extend the activity by asking questions about cultural issues that } \\
\text { red in the story, e.g., Why did Mbok Srini come to see the Hermit? or } \\
\text { related to value or moral issue such as What do you think of actions } \\
\text { Emas/Mbok Srini/Bhuto Ijo?; What do you think will happen? }\end{array}$ \\
\hline
\end{tabular}

Tabel 2. Contoh Kegiatan Sisipan untuk Materi Budaya Internasional atau Asing Lainnya

\begin{tabular}{l} 
Classroom Activity \\
\hline Background story: Based on the Zuni (Native American) legend, Coyote and Eagle's \\
world is overtaken by darkness. They decide bringing light to the world might put \\
things right, but what price comes from taking something that is not yours? The story \\
is a Zuni myth about the origin of winter. \\
Zuni is Native Americans Pueblo people natives to the Zuni River valley (New \\
Mexico). \\
Story theme: Sneaky tricks and whopping lies
\end{tabular}




\begin{tabular}{|l|l|}
\hline Aims & $\begin{array}{l}\text { Skills - listening for details } \\
\text { Language - giving opinions } \\
\text { Other - cooperation, drawing up lists, memorizing, note taking }\end{array}$ \\
\hline Organization & Groups of three to five students \\
\hline Preparation & $\begin{array}{l}\text { Video of 'Coyote and the Eagle' } \\
\text { A set of story pictures (Appendix 1) for instructors only } \\
\text { Handouts for each group (Sequencing worksheet) }\end{array}$ \\
\hline Time & 45-60 minutes \\
\hline Procedure &
\end{tabular}

Step 1: The instructor plays the video and the students watch carefully. The video should be played twice. First viewing, they have to listen carefully. Second viewing, remind the students to listen the video for a purpose, i.e. listening for details. They are not allowed to take notes.

Step 2: The class is divided into groups. Each group receives one Sequencing Worksheet (see attached Sequencing Worksheet). The groups now follow the instructions to look at the pictures shown by the instructor on the board/projector (see Appendix 1). The students cannot have the copy of the pictures, and they also not allowed to take pictures using their mobile phones. The pictures are still shown on the slide while they are doing the work. Give them approximately 15 minutes to complete the whole task.

Step 3: All groups collect the worksheet to the instructor. Then instructor distributes one worksheet to another group, so all the groups receive the worksheet belongs to other group. Once the worksheet is distributed evenly, the instructor shows the correct answers from the slide (see Appendix 2). The group has to correct their friends' works. They can collect the worksheet once they have finished the correction.

\section{Extension}

The instructor can extend the activity by asking questions about cultural issues that may have appeared in the story, e.g., Why the animals are coyote and eagle? or other questions related to value or moral issue such as What do you think of actions taken by the coyote?; What do you think will happen?

\section{SIMPULAN}

Cerita rakyat, legenda, fabel, atau dongeng bisa menjadi alat bantu mempromosikan kesadaran moral, pendidikan dan penguatan karakter, budi pekerti, dan juga lintas budaya bagi guru dan siswa EFL dalam berbagai cara, yaitu kekayaan bahan visual dan audio. Kesadaran akan konten naratif khusus budaya dan nilai moral dalam setiap cerita lokal atau internasional dapat membantu para mahasiswa perguruan tinggi untuk membandingkan dan merangkul persamaan dan perbedaan yang ditimbulkan oleh dua budaya berbeda yang memicu respons kritis dan respons kreatif. Oleh karena itu, mengungkap cerita rakyat, legenda, fabel, atau 
dongeng dalam pembelajaran bahasa asing atau jurusan/program bahasa asing di perguruan tinggi dapat meningkatkan minat, motivasi dalam pembelajaran bahasa, dan kesadaran lintas budaya bagi pengajar dan pelajar bahasa.

\section{UCAPAN TERIMA KASIH}

Tulisan ini merupakan bagian kecil dari hasil penelitian berjudul "Application of Folklore Concepts and Content to Teaching English as a Foreign Language: An Instance of Indonesian Higher Education Students" yang dilaksanakan di Universitas Indraprasta PGRI. Dana penelitian ini dibantu oleh Universitas Indraprasta PGRI Jakarta melalui Lembaga Penelitian dan Pengabdian Masyarakat (LPPM) sesuai dengan Kontrak Program Penelitian Nomor: 0366/SPP/KP/LPPM/UNINDRA/III/2

019. Oleh karena itu, penulis mengucapkan terima kasih kepada ketua LPPM Universitas Indraprasta PGRI Jakarta atas semua bantuanya untuk kelancaran penelitian.

\section{DAFTAR PUSTAKA}

Andriany, L. (2016). Model pendidikan karakter di perguruan tinggi: Terinternalisasi dalam Catur Dharma dan budaya kampus. Pekanbaru, Riau, Indonesia: PT. Anugerah Semesta Persada. Retrieved from https://www.researchgate.net/pu blication/331873781.

Bean, M. S. (2013). The Role of traditional stories in language teaching and learning. In M. R. MacDonald (Ed.), Traditional
Storytelling Today: An International Sourcebook (pp. 548-551). Retrieved from https://books.google.co.id/books ?id=i8RdAgAAQBAJ.

Carter, R., \& McCarthy, M. (2017). Spoken grammar: Where are we and where are we going? Applied Linguistics, 38(1), 120.

DOI: 10.1093/applin/amu080.

Character Education Partnership DC., W. (2008). Character education quality standards: A self-assessment toll for schools and districts. Washington DC: Character Education Partnership. Retrieved from https://eric.ed.gov/?id=ED5050 85.

Chou, M. (2015). The influence of topics on listening strategy use for English for academic purposes. English Language Teaching, 8(2), 44-54. DOI: 10.5539/elt.v8n2p44.

Crawshaw, R., McCarthy, M., \& Carter, R. (1996). Language as discourse: Perspectives for language teaching. The Modern Language Review, 91(3), 677. DOI: $10.2307 / 3734093$.

Dharmawan, N. S. (2014). Implementasi pendidikan karakter bangsa pada mahasiswa di perguruan tinggi. Makalah Disampaikan Pada Pembinaan Pendidikan Karakter Bagi Mahasiswa PTS Di Lingkungan Kopertis Wilayah VIII. Retrieved from https://fkh.unud.ac.id/uploads/w p/2014/09/Pnddkn-KarakterBngs-NS-Dharmawan-2014.pdf.

Dhiu, K. D., \& Bate, N. (2018). Pentingnya pendidikan karakter 
di perguruan tinggi: Kajian teoritis praktis. Jurnal Ilmiah Pendidikan Citra Bakti, Annual Proceeding(November), 172 176. Retrieved from http://ejournal.citrabakti.ac.id/in dex.php/jipcb/article/view/105/6 1 .

Effendy, M. (2018). Panduan praktis pelibatan tripusat pendidikan dalam penguatan pendidikan karakter (PPK) untuk Kepala Sekolah. Jakarta: Pusat Analisis dan Sinkronisasi Kebijakan Setjen Kemdikbud.

Erikson, E. H., \& Erikson, J. M. (1998). The life cycle completed (extended version) (2nd ed.). New York: W. W. Norton \& Company. Retrieved from https://books.google.co.id/books ?id=SKidSuluprgC.

Hambali A, U. J. (2013). Psikologi kepribadian (lanjutan). Malang: Universitas Muhammadiyah Malang.

Hasanah. (2013). Implementasi nilainilai karakter inti di perguruan tinggi. Jurnal Pendidikan Karakter, 3(2), 186-195. DOI: 10.21831/jpk.v2i2.1439.

Hustvedt, S. (2011). Three emotional stories: Reflections on memory, the imagination, narrative, and the self. Neuropsychoanalysis, 13(2), 187-196. DOI: 10.1080/15294145.2011.107736 74.

Ismail, H. N., \& Alexander, J. M. (2005). Learning within scripted and nonscripted peer-tutoring sessions: The malaysian context. Journal of Educational Research, 99(2), 67-77. DOI: 10.3200/JOER.99.2.67-77.

Lwin, S. M. (2015). Using Folktales for language teaching. The English Teacher.

Nussbaum, M. (2018). Education for citizenship in an era of global connection. Contemporary Philosophical Proposals for the University: Toward a Philosophy of Higher Education, 21(4), 145-159. DOI: $\quad 10.1007 / 978-3-319-$ 72128-6_8.

Peraturan Menteri Pendidikan dan Kebudayaan Nomor 81A Tahun 2013 tentang Implementasi Kurikulum.

Peraturan Pemerintah Nomor 32 Tahun 2013 tentang Perubahan Atas Peraturan Pemerintah Nomor 19 Tahun 2005 Tentang Standar Nasional Pendidikan.

Peraturan Presiden Nomor 87 Tahun 2017 tentang Penguatan Pendidikan Karakter.

Read, J. (2018, January 18). Assessing academic listening. The TESOL Encyclopedia of English Language Teaching. DOI:

10.1002/9781118784235.eelt06 15

Samuelson, P. L. (2008). Moral imagination in theory and practice. Georgia: Georgia State University.

Sanchez, S., Gu, H., Kunze, K., \& Inami, M. (2015). Multimodal literacy. In Proceedings of the 2015 ACM International Joint Conference on Pervasive and Ubiquitous Computing and Proceedings of the 2015 ACM International Symposium on Wearable Computers UbiComp '15 (pp. 1257-1260). New York, New York, USA: ACM Press. DOI: 
10.1145/2800835.2807940.

Setiartin R., T. (2016). Transformasi teks cerita rakyat ke dalam bentuk cerita bergambar sebagai model pembelajaran membaca apresiatif. Litera, 15(2), 389401.

DOI:

10.21831/ltr.v15i2.11837.

Tappan, M. B. (1992). Educating for character - how our schools can teach respect and responsibility - Lickona, T. Journal of Teacher Education (1st ed., Vol. 43). Random House Publishing Group. DOI: 10.1177/0022487192043005008

UMY, B. (2015). Pelajaran bahasa Inggris perlu masukkan pendidikan karakter. Retrieved November 29, 2019, from http://www.umy.ac.id/pelajaranbahasa-inggris-perlu-masukkanpendidikan-karakter.html.

Wagner, E. (2014). Using unscripted spoken texts in the teaching of second language listening. TESOL Journal, 5(2), 288-311. DOI: $10.1002 /$ tesj.120.

Wagner, E. (2018). Texts for listening instruction and assessment. The TESOL Encyclopedia of English Language Teaching (pp. 1-6). Hoboken, NJ, USA: John Wiley $\&$ Sons, Inc. DOI: 10.1002/9781118784235.eelt06 26.

Watkins, J., \& Wilkins, M. (2011). Using YouTube in the EFL classroom. Language Education in Asia, 2(1), 113-119. DOI: 10.5746/LEiA/11/V2/I1/A09/W atkins_Wilkins.

Yeldham, M., \& Gruba, P. (2016). The development of individual learners in an L2 listening strategies course. Language Teaching Research, 20(1), 934.

DOI: $10.1177 / 1362168814541723$.

Zuama, S. N. (2014). Kemampuan mengelola stres akademik pada mahasiswa yang sedang skripsi angkatan 2009 Program Studi PG PAUD. Kreatif, 17(2), 7887. Retrieved from http://jurnal.untad.ac.id/jurnal/in dex.php/Kreatif/article/view/29 54. 